Al-Uqud: Journal of Islamic Economics Volume 4 Issue 2, July 2020

E-ISSN 2548-3544, P-ISSN 2549-0850～DOI:10.26740/al-uqud.v4n2.p268-284

Accredited No. 28/E/KPT/2019

Page 268-284

\title{
Halal Tourism Based on Value Creation
}

\section{Ririn Tri Ratnasari}

Department of Islamic Economics, Faculty of Economics and Business, Universitas Airlangga, Jalan Airlangga, Gubeng, Surabaya 60286, Indonesia

\begin{abstract}
Nowadays, halal tourism product is not only focused on Muslim tourists, but also non-Muslim one. The halal tourism industry needs to develop the people understanding of halal values in order to bring benefits to consumers through recognition of the tourism management potency as well as the need of value identification. This research aimed to develop value-based tourism, identify the value types, as well as create value as the basis for managing lawful tourism, which needs a model to facilitate recognizion of the tourism product excellence. This research used qualitative case study approach, with the head of tourism in the region where has potency to implement Islamic Marketing Concept as the key informants. The result showed that halal marketing included not only about product but also about pricing, promotion, and place. Muslim consumers were keen on tourism services that implement lawful approach. Furthermore, there were ten values of tourism in Indonesia e.g. Religious Tourism, Geo Tourism, Natural Tourism, Fashion Tourism, Culinary Tourism, Medical Tourism, Historical Tourism, Sport Tourism, Culture Tourism, and Hospitality Tourism.
\end{abstract}

Keywords: Halal; Tourism; Value Creation

Paper type: Research paper

*Corresponding author: ririnsari@feb.unair.ac.id

Received: May 27, 2020; Accepted: Juny 27, 2020; Published: July 01, 2020

Cite this document:

Ratnasari, R. T., (2020). Halal Tourism Based on Value Creation. Al-Uqud: Journal of Islamic Economics, 4(2), 268-284. doi: http://dx.doi.org/10.26740/al-uqud.v4n2.p268-284

Copyright () 2020, Al-Uqud: Journal of Islamic Economics http://journal.unesa.ac.id/index.php/jie 


\begin{abstract}
Abstrak: Produk wisata halal saat ini tidak hanya difokuskan pada wisatawan Muslim, tetapi juga bagi wisatawan non-Muslim. Industri pariwisata halal perlu mengembangkan pemahaman masyarakat tentang nilai-nilai yang halal untuk memberikan manfaat bagi konsumen dengan mengenali potensi pengelolaan pariwisata serta kebutuhan untuk mengidentifikasi nilai-nilai tersebut. Tujuan penelitian ini adalah bagaimana mengembangkan pariwisata berbasis nilai, mengidentifikasi jenis nilai serta menciptakan nilai sebagai dasar pengelolaan pariwisata yang halal. Diperlukan suatu model yang memudahkan untuk mengenali keunggulan suatu produk, termasuk produk pariwisata tersebut. Metode yang digunakan dalam penelitian ini adalah pendekatan kualitatif studi kasus. Informan yang digunakan dalam penelitian ini adalah kepala pariwisata daerah yang berpotensi menerapkan konsep pemasaran syariah. Hasil penelitian ini menunjukkan bahwa ruang lingkup pemasaran halal tidak hanya pada aspek produk tetapi juga harga, promosi, dan tempat. Konsumen Muslim bersikap positif terhadap layanan yang menggunakan pendekatan halal. Selain itu terdapat sepuluh model jenis pariwisata di Indonesia berdasarkan nilai, yaitu: Nilai wisata sakral, nilai geo, nilai wisata alam, nilai wisata fashion, nilai wisata kuliner, nilai wisata medis, nilai wisata nostalgia, nilai wisata olah raga, nilai wisata budaya, dan nilai pariwisata perhotelan.
\end{abstract}

Kata kunci: Pariwisata; Halal; Nilai

\title{
INTRODUCTION
}

As a Muslim majority country, Indonesia has the largest Muslim population (Ratnasari et al., 2020). According to BPS (Central Bureau of Statistics:2017), $87.1 \%$ of the total Indonesia population is Muslim, which comprises of $11.5 \%$ of total Muslim in the world. Hence, generally it can be concluded that most of Indonesian already use Sharia as a basis for day-to-day activities. Sharia is not only refers to the practices of mahdhah worship, but also the practices of human relations, including in trade or marketing activities (Jafari and Scott, 2013). The Islamic marketing development has evolved to the modern marketing modelled by Muslim norms and values, even the corresponding academic literature stands out for its importance and applicability, generating new concepts and theories (Wilson et al., 2013).

The rapid increase in the Muslim population makes halal products considered as a great business opportunity. However, currently halal product is only referring to food, while halal is more than just food. There is more about halal products and services e.g. tourism. Over the past few years, the relationship between Islam and tourism has attracted and increasing people interest (VargasSánchez and Moral-Moral, 2019). Halal tourism has a great potential to increase, the easier and the more affordable tour allow Muslims to travel abroad nowadays. Global Muslim expenses for travel (excluding Hajj and Umrah) was \$ 142 billion in 2014 and this was $11 \%$ of the total global expenditure in the same year. The number had increased from $\$ 134$ billion (about $6.3 \%$ of the total global expenditure of Muslims travel expenses) in 2013. In 2020, the total global expenditure of Muslims travel expenses expected to increase to $\$ 233$, on average, the third largest Muslim travel expenses after China ( $\$ 160$ billion) and the United States (\$143 billion) (Thomson Reuters, 2015). The population of Muslim in the world is expected to reach 2.2 billion by 2030 and Muslims will make up $26.4 \%$ 
of the world's total projected population of 8.3 billion in 2030. In 2017, it was determined that 131 million Muslim tourists joined tourism activities. It is predicted that it will reach 156 million visitors in 2020 that will represent $10 \%$ of global travel segment (Mastercard and CrescentRating, 2018). Indonesia tourism industry has contributed more than $13 \%$ of GDP since 2017 . Besides, its revenue has increased to 223.0 billion Rupiah in 2018 from from 182.0 billion Rupiah in 2017 (Ratnasari et al., 2020). Tourism industry has a potency to become a major economic driver of a nation, especially in Indonesia, a developing country that aiming to diversify its income streams (Ratnasari et al., 2020).

Muslim expenditure for tourism activities are predicted to increase continuously. Hence, it creates a major opportunity for the country to increase its foreign exchange earnings. Moreover, Muslim travellers usually travel with many family members and stay longer, thus they spend more (Halal Tourism, 2015). Nowadays, the usage of Islamic terminology in economic activity spreads widely in various business sectors. It started in 1992, with the emergence of Islamic Banking, then followed by others e.g. Islamic Insurance, Islamic Pawnbroker. It followed then by Halal Tourism and Hotel in 2013, supported with Indonesia high potency in tourism destinations, cultures, population, and the parties involved.

Amongst total world population, 23.4\% are Muslim. Further, it is estimated to increase to $26.4 \%$ with the average growth of $1.5 \%$ per year in 2030 . Thus, it created large market of Halal Tourism. The total expenditure of Halal Food and Lifestyle by Muslim people in 2012 reached US \$ 1.6 trillion and grew to US \$ 2.47 trillion in 2018. In Indonesia, according to the General Director of Tourism Marketing (Kemenparekraf), in 2013 there was 1,434,039 foreign Muslim tourists come that not only from Middle East region, but also from other countries.

Halal tourism industry needs to educate people that halal industry is more than visiting the Holy, Religious, and Historical sites in Muslim Countries. It needs to develop the people understanding universally and comprehensively about halal tourism toward the services provide, e.g. the culinary service, more than the places itself (Mohsin et al., 2016).

Moreover, value creation is important for tourism service providers, since there is a burnout in the tourism market (Avci, Madanoglu, \& Okumus, 2011; Fitzpatrick, Davey, Muller, \& Davey, 2013; Grissemann \& Stokburger-Sauer, 2012, in O'Cass \& Airs, 2015). Tourism managers need to understand that customers need other values to satisfy them. In the managerial perspective, they can find the value sought by the customers then develop and offer it uniquely (O'Cass \& Airs, 2015). The value creation is about how the company outperform its competitors by creating and offering superior value to its customers. As in halal tourism, it can be represented by creating and offering Islamic value as well.

Thus, the development of halal tourism, with value-based tourism, universally benefitted the customers. Recognition of tourism potential, as well as identification of the types of value-based tourism could emphasis the attractiveness of the tourist attraction. This research attempted to explore the development of value-based tourism and identify types of value as well as create value as the basis for managing lawful tourism. Vargas-Sánchez, A. and MoralMoral, M., 2019; Ratnasari et al., 2020; Samori, Nor, \& Mohammad, 2016 had 
discussed about Halal tourism, but there is no discussion on Halal tourism based on value creation so far, therefore this study explored the value creation as the base of Halal tourism.

\section{Definition of Halal Tourism}

Halal tourism is one of the tourism systems designated to comply the Sharia, hence match the Muslim travellers need. It has been introduced since 2000 from the OIC meeting discussion. Halal tourism is a tourism based on the lifestyle of Muslim travellers during the holidays. Further, it is also a rational, flexible, simple, and balance tourism. It aims to motivate the travellers to get happiness and blessing of Allah SWT.

Halal tourism could be defined as a wide range of tourist activities, supported by a wide range of facilities and services provided by communities, businesses, and governments that comply with sharia. Halal tourism has the characteristics of universal products and services, its existence could be used by all people of humanity (rahmatan lil'alamin). Halal tourism basically is the same as tourism in general, but it avoids all the prohibited in Islam, hence it is complied the Sharia. For non-Muslims, these rules might somewhat limit their freedoms and old habits.

Islamic Tourism Center (ITC) Malaysia defines Halal tourism as an activity, event, experience, where the journey undertaken is in accordance with the teachings of Islam, which includes travel history, art, culture, heritage, way of life, economy, health, education, and other human interest (Mahmud, 2014). Halal tourism is more than the halal culinary or pilgrimage. According to Chookaew (2015), halal tourism term tends to be unfamiliar in the tourism business. Halal tourism is defined as religious tourism, for example visiting to places of worship for pilgrimage or other places of worship. In fact, halal tourism is not about the object but the etiquette of traveling and other amenities. The destination does not have to have Islamic nuances objects, such as a relic of the history of Islam and the mosque.

Halal tourism is difference to other tourism since its purpose and motivation to travel is not based on pleasure and hedonistic (Din, 1989; Sanad, Kassem, and Scott, 2010, in Samori et al., 2016). Religion affects the daily activity of a Muslim, whether at home or while traveling, thus it affects the choice of travel destinations and travelling activities (Jafari \& Scot, 2014 in Samori et al., 2016). Samori et al. (2016) explains that Muslim recommendation to travel around the world is to ponder God's creation. This is in accordance with al-Qur'an surah Al-An'am verse 11: "Travel through the earth and see the retaliation of those who denied it". Muslim countries tend to interpret tourism based on what the Qur'an says. The following forms of tourism based on Qur'an (Kovjanic, 2014):

(1) Hijja. Involves travel and pilgrimage to Mecca. This trip requirement for every healthy adult Muslim. At least once in a lifetime to take the pilgrimage.

(2) Zejara. Refers to a visit to the holy places of other.

(3) Rihla. Is a trip for other reasons, such as trade and education. 
The emphasis is on the directional movement, as a component of a spiritual journey in the service of God. Sharia determines what is acceptable (halal), and what is not acceptable (haram) both in daily life and during the trip (Kovjanic, 2014). Islam considers any acts judged by the intention. As a consequence, Muslims traveling to achieve certain objectives of physical, social, and spiritual. Therefore, tourism in Islam is a goal-oriented activity with motivation of fisabilillah. Tourism is a mean to realize that human is subject to God, God is great, and and strengthen the bonds of brotherhood (Din, 1989, in Mahmud, 2014).

Halal tourism is included in the category of religious tourism. The word comes from the Arabic, means permitted, accepted and allowed. Halal is not limited to food and drink, but covers all aspects of Muslim life (El-Gohary, 2016). In Islamic perspective, tourism product can embed more value to travellers through the experiences of halal travel. This value covers the necessity to be beneficial to others, be honest, and only consume products which are only permitted by Allah. Tourism in Islam only related to Hajj and Umrah (ElGohary, 2016). However, Muslim can perform halal travel for this reason, they can worship Allah as well as inquire about local traditions, seek and learn knowledge, learn life lessons as a reminder, contemplate the wonders of Allah creation, and enjoy the beauty of universe (El-Gohary, 2016).

\section{Halal Tourism Based on Value Creation}

Eid and El-Gohary (2015) explained that the customers' or tourists perceived value in the hospitality and tourism provider, have recently become the object of research interest. In the managerial perspective, when the company succeed to find the value sought by customers, it can be considered as successful differentiation strategy (O'Cass \& Airs, 2015). The concept of value creation is used to describe how some companies can outperform its competitors by creating and offering superior value to customers. It has been recognized also that customers are looking for superior value in various ways (Sparks et al., 2011, in O'Cass \& Airs, 2015).

Value creation is important for tourism service providers (e.g. hotels, travel agents, tourist destinations, and others), because the segment of the tourism market experiencing burnout (Avci, Madanoglu, \& Okumus, 2011; Fitzpatrick, Davey, Muller, \& Davey, 2013; Grissemann \& Stokburger-Sauer, 2012, in O'Cass \& Airs, 2015). In order to satisfy the customer, the tourism provider need to understand the necessity of additional value to its services. It can be done by development of its unique service value (O'Cass \& Airs, 2015). The nature of the environment can be utilized as an idea sources in value creation. Hence, it can be said anyone, in the tourism business, could lead to value creation (Altinay et al., $\underline{2016)}$.

Religiosity plays an important role in terms of consumption, including the hotel and tourism selection by Muslim customers. Religiosity taught Muslim tourists about the code of conduct that could serve as guidelines during the travelling time, e.g. tourists will avoid alcoholic beverages during the tour (Jafari 
and Scott, 2014). Such examples can be used as an opportunity to develop the concept of value creation in Halal tourism.

Halal tourism has distinctive features in the "airport" rating on the basis of the Qur'an and Hadith. However, it is not just for Muslim tourist, since, principally, Sharia implementation intended to rid harmful things toward humanity as well as the environment where the products and services supplied. Generally, it provides more benefit, since Islam is Rahmatan Lil-Alamin. Halal Tourism should be worth substantially rather than artificially, e.g. Decorated tourist attractions in Middle East style is merely artificial. Halal travel and tourism is more than pilgrimage or religious tour.

Halal Tourism is a Muslim friendly tourism (Ziauddin, 2015). There is no prohibition of travelling in Islam, so long it follows Sharia. There are several verses in the Qur'an that explain about travelling as following

"Say:" Walk in the (face) of the earth, then see how God created (men) from the outset, then Allah makes it once again. God has power over all things. "(QS. Al-Ankabut: 20)

"Have they not travelled in the land so that they can pay attention to how the end of those before them; God has inflicted misery upon them, and the disbelievers will accept (the effects of) like that. "(QS. Muhammad: 10)

"He Who has made the earth it easy for you, so they went up at every turn, and eat his party of sustenance. And unto Him you (come back after) are raised. "(QS. Al-Mulk: 15)

"... and cried out to the man to do the pilgrimage, they will come to you on foot and camel riding skinny coming from every corner of the remote. So that they may witness the benefits to them and mention the name of Allah on appointed day over the sustenance which God has given them in the form of livestock. So, eat some, and give some for the poor people who are miserable and indigent to eat. Then, let them remove the dirt that is on their bodies and let them enhance their vows and let them perform tawaf around the old house (House)“'(QS. Al-Hajj: 27-29).

Based on the verses, the goals of travelling in Islam are:

(1) View and admire the creations of Allah

(2) Seeking knowledge and experience

(3) Introduce Islam

(4) Strengthens kinship

(5) Entertainment

Indonesia has great potency in halal tourism, an opportunity to be developed for the travel providers. They can target Muslim travellers through halal tour establishment e.g. the availability of halal food and beverage, customized itinerary with prayer times and easiness to pray at the local mosque, as well as provision of Muslim tour guide. They can also design tour packages to Muslim minority countries, to trace the Islamic history and culture, thus the travellers can learn about the faith struggle of Muslim as a minority. 
Travel agent should add education and religious value out of its recreational purpose. More than just Islamic Heritage, the travel package should also provide visit to local Muslim community, local mosques, as well as the halal culinary destination (Othman et al., 2015). Travel agents have many opportunities to develop Halal Tourism, i.e. halal-business travel, family-friendly packages, Muslim-friendly services, luxury market, Muslim segment and Muslim heritage souvenirs (Battour and Ismail, 2016). Further, Battour and Ismail (2016) stated that Turkey, Egypt, and the UAE are trying to attract Muslim tourist by creating pool for women that allow Muslim swimwear. There is also a Halal cruise, that was first launched by the Antalya-based Tour Company in Turkey.

Chookaew et al. (2015) showed that the rapidly growing of halal economy provides ample opportunities in the world of tourism, particularly the halal tourism development. The halal concept, in tourism, can be applied in halal hotel, lawful transportation, halal food premises, halal logistics, Islamic travel packages, Islamic finance and halal spa. Even more, Muslim friendly airport will be growing in the world because of the growing number of Muslim travellers in world.

\section{RESEARCH METHODS}

This study used descriptive qualitative approach. The data obtained through interview with key informants, the Head of Tourism Department of the province or district where has the potency to implement Islamic marketing concept. The Islamic economic move wider, i.e. the emerging of two Islamic Traditional Markets in Surabaya, East Java and Lombok at West Nusa Tenggara (Dhakoir, 2018). Meanwhile Jakarta has the potential for halal market, as the capital of Indonesia with an area of $664.01 \mathrm{~km}^{2}$ and an 8,200,796 Muslim out of 9,998,495 people (Briliana \& Mursito, 2017). Also, Bandung, West Java, the third most populous city in after Jakarta and Surabaya. Bandung was originally developed as a resort city in the 1800 s by the Dutch Indies government, because of the rich natural setting and comfortable climate (Voskuil, 2007). Hence, the research was conducted in Jakarta, Mataram (Lombok), Surabaya, and Bandung.

\section{RESULTS AND DISCUSSION}

Currently the halal tourism is not only focused on Muslim travellers, but also nonMuslim one. Halal products have been the choice of living in the world, since it not only complies with Sharia but also nourish the body (KH Amidhan).

The result showed that Islamic marketers conduct marketing efforts that promote the values of a noble character. Thus, the scope of Halal Marketing is not only in the aspect of product (e.g. contain no forbidden substances or materials) but also pricing (e.g. pricing that does not contain gambling, gharar and usury), promotion (e.g. no deception, no sexual appealing in commercials), and also a place (e.g. do not sell in places that are prohibited such as mosques or at such time that banned prayer in congregation). Some people think that the Sharia curb creativity because a lot of things that are prohibited, when actually what is permitted by Allah far more than what is prohibited. Based on the arguments of Al-Qur`an and Sunnah, the scholars formulated that the basic rule of muamalah is 
allowed unless there is argument that forbid the activity (Imam As-Suyuti, AlAsybah wa An-Nadzha' ir, I / 60). The scholars stated that Allah forbids something because it contains haram ingredients or anything harmful and dangerous, therefore, the sharia should be the source of inspiration for marketers to further hone their creativity to produce the creative marketing and does not violate the Sharia (Chanin et al., 2015).

The emergence of portal online booking such as halalbookings.com and halaltrips.com is a sign of halal tourism growth. Various surveys showed that halal food is a major factor to attract Muslim tourist (Mohsin, 2016). Its proficiency level shows that Muslim consumers tend to use lawful services.

Halal travel is the realm of the fastest growing of the global tourism. The best service can make tourists impressed, this will lead to a word-of-mouth strategy. Their halal tourism, halal hotels, halal restaurants, halal spa, and more needs to firmly maintain its operation in line with the principles of halal (Chookaew et al. , 2015), The Halal tourism management should be applied to keep consumer trust, since the customer, Muslim particularly, most likely demand qualified products that comply with Sharia. This market segment opportunities are interesting because it has a greater tendency to recommend products and even pay a higher price if there is no alternative to similar halal products that they perceive.

Second, the results showed that halal tourism in Indonesia, can be divided into several types of values, as follows:

\section{Religious Tourism}

Religious tourism has existed in Indonesia since a long time ago, one of which is the pilgrimage tourism. The most familiar pilgrimage tour in Indonesia is Wali Songo. However, the tourist sites have not been well developed and managed, unlike Taj Mahal in India or the Pyramids in Egypt, hence the values added are less significant.

Besides Wali Songo sites, Indonesia has other pilgrimage tourist destination e.g. Cheng Hoo mosque in Surabaya (East Java). The characteristic of Cheng Hoo Mosque is a blend of Chinese and Arabic styles. On the north side of Cheng Hoo Mosque, there is a replica of the ship and the face of Admiral Cheng Ho, whereas the Middle East nuances visible at the main door of the mosque. Reliefs and replica of the ship and Cheng Hoo is constructed to show that Muhammad Cheng Hoo is a sailor, a devout and pious Muslim Chinese, as well as the ambassador of peace. It has been visited by many foreign tourists, both Muslims and nonMuslims, from Malaysia, Saudi Arabia, China, New Zealand, England, Africa and others (Jajeli, 2013). The tourists come not only to see_and admire the creations of Allah through the architectural beauty of Cheng Hoo mosque, but also to learn about Muhammad Cheng Hoo story.

\section{Geo Tourism}

Halal travel can also specifically direct tourists on a sightseeing trip that allow tourist to have a "back to nature" journey or reflection on Allah's creation in the universe. Tadabur on the nature makes us a humble person and direct us to 
maintain the harmonization of the universe (eco-tourism). Thus, motivates Muslim travellers to always read, research, understand, and actualize themselves to be a grateful and clever servant, this is where the benefits obtained by the Muslim travellers. Nowadays, there are 9 Islamic destinations in Indonesia, namely West Sumatra, Riau, Lampung, Banten, Jakarta, West Java, East Java, Makassar and Lombok.

\section{Natural Tourism}

Halal tourism is not exclusively in the context of religious tourism, it also be in the form of natural tourism. Asides from religious sites, there are many tourist destinations can be introduced, i.e. an active crater, to raise critical interest of the tourist. So long that it is professionally managed and secured, the prospect of halal tourism will be flourished and has a competitive advantage.

Indonesia possess wide variety of very interesting natural objects, e.g. the beach, mountains, and lakes. Those Natural objects is also equipped with the facility to be more familiar with the nature, i.e. facilitating fly over, climbing, crossing sea etc, hence the tourist could enjoy the beauty of the nature as well as run into the natural experiences. Moreover, while enjoying the natural beauty of Indonesia, the traveller can see and admire the creations of Allah SWT. Travellers can contemplate the greatness of Allah SWT through the existence of all creations on the earth.

\section{Fashion Tourism Value}

Ryan (2016) explained that tourists, who visit a particular place, not only bring money but also come up with ideas and support on a particular community, i.e. the fashion community. Muslim women must wear clothes that cover the aurat, for example using a hijab. Indonesia has well known Muslim designer, e.g. Dian Pelangi and Zaskia Sungkar, who often perform fashion show in various fashion events. Sapta, Deputy Minister of Tourism, stated that Indonesia is optimistic to be the centre of Muslim fashion trendsetter in 2020, because Indonesia has designers that proficient in making unique and creative fashion. Dian Pelangi, as an example, held a successful fashion show themed "Washington Haute and Modesty" in DC fashion Week, Washington DC, USA. Sapta added that if Indonesia can claim the position of Muslims fashion trendsetter, it will affect the economic growth of the fashion industry as well as the tourism sector. In a way, there will be a lot of foreign tourists who come to Indonesia to stay update on the latest trend of Islamic fashion. The fashion industry contributed around $28.3 \%$ of GDP creative economy in 2013 (Adimaja, 2014). Fashion tourism can also be used as a way of friendship (sillaturahim), whereby Muslims from different countries can meet to discuss the trend of Muslim clothing. Nowadays, many Muslim women from several countries, includes Russia, visit Indonesia to update the development of Islamic fashion.

\section{Culinary Tourism}

Though it is called Halal Tourism and applied based on Sharia, the tour is not exclusive to Muslim travellers only. Non-Muslim travellers can also enjoy the 
tour, such as halal restaurant that guarantee the standards and so forth. Euro monitor International reports that halal food sales in Europe increased due to the number of Muslim tourists visiting Europe. Investment in halal food market is expected to grow in the Muslim minority country, due to the growth of Halal tourism. Muslims globally expenditure on food and beverages is expected to rise to $\$ 2.537$ billion in 2019 and will increase to $21.2 \%$ of global spending. The Middle Eastern full-service and fast food restaurants that serves halal food are very popular in UK, France, and Germany, where some of their customers often are non-Muslims (Battour and Ismail, 2016).

Wijaya et al. (2016) said that prior the visit to Indonesia, some tourists have heard about the local Indonesian food. The travellers often find out the information through word-of-mouth (WOM) from friends, family, and relatives, as well as from the written sources such as magazine articles about Indonesian cuisine. Words that frequently appear in the traveller's mind are ricebased, spicy, tasty, sweet, mostly fried, herbs spices, chili, and halal food. The interesting point was, foreign tourists already consider the local Indonesian food as halal food. Since Indonesia has the largest Muslim population in the world, Indonesian cuisine is assumed that already cooked according to the teachings of Islam that is free from unlawful materials.

Moreover, with the easiness to broadcast and spread the specific message to wide customers through social media, it can appear as social keepers toward the Muslim customer rights. Once there is any concern that some products may have violated the rights of Muslim customer to consume Halal product, there will be suggestion or even petition to boycott the product that spread easily. Hence, the business owners should pay attention to make sure that its product or services is provided in accordance to Sharia or else they could possibly face the loss of sales, market share, brand equity, and customer loyalty.

\section{Medical Tourism}

Medical tourism or healthcare tourism refers to traveling across the country for the purpose of medical treatment. The growth of the pharmaceutical industry is lawful and public awareness to it also contributes to the growth of travel with health goals. Muslim friendly healthcare is relating to the provision of Muslim friendly at hospitals and other health services. Islam allows for eating non-halal items only in things concerning life and death. Some hospital also did not provide drugs that contain pork or instance, insulin -containing pork is replaced with other insulin it that does not violate the teachings of Islam (COMCEC Coordination Office, 2016).

Medical tourism (med-tour) is efforts of medical tourists visits other countries to obtain medical services, in the context of healing and relaxation (Abubakar and Ilkan, 2016). Med-tour is a combination of products and services of the healthcare industry and the tourism industry together, for example in health packages and holiday (Abubakar and Ilkan, 2016). One example of medical tourism is Halal Spa. Applying the Islamic Spa Practice concept is not only on the services offered but also in an execution of business operations including the use of verses of the holy Quran which was also 
seen further streamline the country's image as a medium for the concept of halal industry. Besides, spa service, beauty therapist segregation by sex, the use of rooms and the different services to clients both men and women are also among the attractions of this spa in accordance with Islamic law (Yaman et al., 2012). Indonesia was elected as the best spa for tourist destination through awards bestowed in International Wellness Awards in the International Travel Bourse in Berlin, Germany, Indonesia through Bali has been voted as "The Best Spa Destination in The World” in 2009 (http_www_republika_co_id).

\section{Historical Tourism}

At the awards World Halal Tourism Awards in 2015, Indonesia has won in the category of World's Best Halal Cultural Destination. Jakarta has a fascinating Old Town, which has been proposed to be a UNESCO world heritage status in January 2016. Kota Tua Jakarta in the past was a contested city that became a symbol of glory for anyone who was able to master it. Formerly in the 16th century the region was dubbed the "Jewel of Asia" and "Queen of the East" by European sailors, Old Jakarta was considered a trading center for the Asian Continent due to its strategic location and abundant resources. The Kota Tua area holds high historical value, various relics of the past can still be found in this Kota Tua area. In the Kota Tua area there are also several tourist attractions that can be visited, such as Fatahillah Museum, Sunda Kelapa Harbor, Bank Indonesia Museum and Bank Mandiri Museum, Wayang Museum, Fine Arts and Ceramics Museum and Red Shop. In addition to tourist attractions, the Kota Tua area is also often used as a photo spot, because the area has not changed much, such as the Dutch colonial era (Jakarta.go.id). East Java also has a historical tourism i.e. Trowulan in Mojokerto, the Trowulan site has an area of nearly $100 \mathrm{~km} 2$. With such an area, the Trowulan Site in Mojokerto has several temples such as Brahu Temple, Tikus Temple, Bajang Ratu Temple, and Kedaton Temple. Not only the temples, there are also fresh ponds, the tomb of the queen of Brawijaya, the Majapahit pavilion and the tomb of Sheikh Junaidul Qubro. Besides that, the center of attention is the Sleeping Buddha statue. The Sleeping Buddha statue is 22 meters long by 6 meters wide and 4.5 meters high. The statue is the largest Sleeping Buddha statue in Indonesia (Liputan6, 2019).

\section{Sport Tourism}

Sports tourism is one of the largest and fastest growing segments of travel and tourism industry. Sports tourism is any form of involvement of both active and passive in sports activities, in which sport is the main motivation in the tour (World Tourism Organization, 2010, in Singh et al. (2016). Travellers prefer eco-friendly sport activities due to their concern on environment. It is not surprising that cities, regional, and countries in the world boost sports tourism market, such as golf, mountain climbing and skiing. In some countries such the United Kingdom (UK), sports tourism contributes to state income until 20\% (Singh et al., 2016).

Sports tourism is composed of hard and soft. Hard sport is intended to attract a large number of visitors to a particular place to watch a show in group 
settings such as the Olympics, World Cup, F1, and others. Soft sport tourism refers to tourists traveling to participate in sports activities, such as hiking, skiing, rafting, and other activity classified as mild sports tourism and related to ecotourism (Singh et al., 2016). Indonesia has the potential of their sport tourism, such as rafting in Probolinggo and Malang (East Java), mountaineering example Rinjani (Nusa Tenggara Barat), Mount Semeru (East Java), Mount Ijen (East Java), Mount Bromo (East Java), and other mountains. Indonesia also has a beach with waves that grace the beauty that can be used for surfing such as in Plengkung, Banyuwangi (East Java) that has one of the seven best waves in the world.

\section{Culture Tourism}

Indonesia is born from different cultures where each region in Indonesia has a distinctive and unique culture. It can be a competitive value for cultural tourism in Indonesia. Both domestic or foreign tourists can be pampered with variety of Indonesian culture. For example, when visiting Bali. The most famous tourist areas of Bali are Tanah Lot, where the tourists love to take picture because there is a temple and its impressive sunset scenery. Provision of cultural experience in tourism is the power of tourism that offers Muslimfriendly tourism (COMCEC Coordination Office, 2016).

Tazbir, deputy assistant business and development marketing segment Ministry of Tourism, said that the West Sumatra and Aceh also has potential for development halal tourism as cultural tourism because of West Sumatra is also known as the religious. West Sumatra and Aceh are expected to follow in the footsteps of West Nusa Tenggara in halal tourism development (Abdussalam, 2016). Aceh is famous for Saman Dance, which has named as Intangible Heritage of Culture by UNESCO in 2011, that can attract tourists to visit and dig deeper into Indonesia tourism (Ward, 2014).

\section{Hospitality Tourism}

Travel agency should able to prepare a schedule of prayer and provide halal food during the trip. Hotels need to prepare all the needs of Muslim travellers, i.e. provide direction to Qibla, serve halal food and non-alcoholic beverages, as well as provide adequate toilet. Halal tourism can be defined as a wide range of tourist activities, businesses, governments, and local governments that comply with sharia.

Recently, travel agents provide "Halal Holiday" packages which provides a full holiday services in accordance with the sharia. The package has the services of halal resorts and hotels that only provide halal food and beverages that alcohol-free. Besides, they also offer swimming pool, spa and leisure facilities, as well as the beach where there is separation between women and men, amenities on family atmosphere, and religious facilities.

Several tour packages also offer tourists visiting Islamic heritage to explore local history and Islamic culture. Some travel agents can emphasize that their activities are directed to defend the values of Islam in terms travel and tourism, to see the signs and patterns of the God greatness in the world (Battour and Islmail, 2016). 
Halal tourism is in line with Law Number 10 Year 2009 on Tourism, whereby the development of sustainable tourism and also about the code of ethics of world tourism which upholds the culture and local wisdom. Later, products and travel services, tourist attractions in the sharia is the same with the products, services, objects and purposes of tourism in general. Halal tourism has the characteristics of products and services that are universal. The existence of this infrastructure is very supportive for travel activities. With the availability of facilities and infrastructure, tourists will feel pampered. In general, for the famous tourist areas, Indonesia offers facilities and infrastructures to complete the inn / hotel, shopping and souvenirs, restaurants and others in accordance with the uniqueness of these tourist areas. For example, when the tourist area is a beach with waves as the attraction, usually places such as surfing equipment rental will be provided. Seamless mobility coupled with the friendliness of the local community are also the most sought hence that they can feel safe and comfortable with the tour.

\section{CONCLUSION}

The results of this study showed that the scope of halal marketing is not only in the aspect of product but also in the pricing, promotion, and also place, and Muslim consumers are leaning on the services that use lawful approach. Hence, Halal tourism management should be applied to keep consumer trust, since the Islamic customer segment demand not only quality products but also comply with Sharia. It resulted on ten models of value-based tourism in Indonesia, e.g. Religious, Geo, Natural, Fashion, Culinary, Medical, Historical, Sport, Culture, and Hospitality tourism value.

This study showed that Wali Songo sites has not been well developed, hence the values added are less significant, meanwhile in the international community there are tourist destinations namely Taj Mahal in India, the Pyramids in Egypt that have pilgrimage tour with good management. The result of the study would help the industry player especially halal travel and tourism industry to plan and strategize on diversifying and promoting halal tourism and travel among their existing and potential customers. Since the study only conducted in Jakarta, Mataram (Lombok), Surabaya, and Bandung, the result is limited to those cities only, and could not be considered as the general result since every city has different characteristics. Hence further study in another cities is suggested.

\section{REFERENCES}

Abdussalam, A. (2016, 8 April). Indonesia Developing Halal Tourism, (Online), retrieved from http://www.antaranews.com/en/news/104074/indonesiadeveloping-halal-tourism, accessed 15 September 2016.

Abubakar, A. M., \& Ilkan, M. (2016). Impact of online WOM on destination trust and intention to travel: A medical tourism perspective. Journal of Destination Marketing \& Management, 5(3), 192-201. https://doi.org/10.1016/j.jdmm.2015.12.005

Adimaja, M. (2014, October 16). Indonesia to Soon Become Trendsetter in IslamicFashion , ( Online), retrieved

from 
http://www.antaranews.com/en/news/96103/indonesia-to-soon-becometrendsetter-in-islamic-fashion, accessed 15 September 2016.

Altinay, L., Marianna S., \& Victoria W. (2016). Social Value Creation through Tourism Enterprise. Tourism Management, 54, 404-417. https://doi.org/10.1016/j.annals.2009.01.002

Battour, M. \& Mohd N. I. (2016) Halal Tourism: Concepts, Practices, Challenges and Future. Tourism Management Perspectives, 19, 150-154. https://doi.org/10.1016/j.tmp.2015.12.008

Battour, M., Hakimian, F., Ismail, M. and Boğan, E. (2018).The perception of non-Muslim tourists towards halal tourism: Evidence from Turkey and Malaysia. Journal of Islamic Marketing, Vol. 9 No. 4, pp. 823840. https://doi.org/10.1108/JIMA-07-2017-0072

Boğan, E. and Sarışı1k, M. (2019). Halal tourism: conceptual and practical challenges. Journal of Islamic Marketing, Vol. 10 No. 1, pp. 8796. https://doi.org/10.1108/JIMA-06-2017-0066

Briliana, V., \& Mursito, N. (2017). Exploring antecedents and consequences of Indonesian Muslim youths' attitude towards halal cosmetic products: A case study in Jakarta. Asia Pacific Management Review, 22(4), 176-184. https://doi.org/10.1016/j.apmrv.2017.07.012

Chanin, O., Piangpis S., Hamzah A. R., \& Mohd S. D. (2015). Guidelines on Halal Tourism Management in the Andaman Sea Coast of Thailand. Journal of Economics, Business and Management, 3(8). joebm.com/papers/287T10009.pdf

Chookaew, S., Oraphan C., Jirapa C., Pingpis S., \& Sudarat N. (2015). Increasing Tourism Potential at Andaman Halal Gulf in Thailand for Muslim Country. Journal of Economics, Business and Management, 3 (7). 10.7763/JOEBM.2015.V3.277

Committee for Economic and Commercial Cooperation of the Organization of Islamic Cooperation (COMCEC). (2016, February). Muslim Friendly Tourism: Understanding the Demand and Supply Sides in the OIC Member Countries (www.comcec.org). Turkey.http://www.sbb.gov.tr/wpcontent/uploads/2018/11/Muslim_Friendly_Tourism_Understanding_the_D emand_and_Supply_Sides_in_the_OIC_Member_Countries\%E2\%80\%8B.p df

Dakhoir, Ahmad. (2018). "Indonesia Tuan Rumah Annual Meeting IMF 2018, "Selamat Datang di Pusat Halal Dunia." Tribun Kalteng.com. https://kalteng.tribunnews.com/2018/07/26/opini-indonesia-tuan-rumahjelang-annaul-meeting-imf-2018-selamat-datang-di-pusat-halal-dunia.

Eid, R., \& Hatem E. G. (2015). The Role of Islamic Religiosity on The Relationship Between Perceived Value and Tourist Satisfaction . Tourism Management , 46, 477-488. https://doi.org/10.1016/j.tourman.2014.08.003

El-Gohary, H. (2016). Halal tourism, is it really Halal?. Tourism Management Perspectives, 19, 124-130. https://doi.org/10.1016/j.tmp.2015.12.013

Harahsheh, S., Haddad, R. and Alshorman, M. (2019). Implications of marketing Jordan as a Halal tourism destination. Journal of Islamic Marketing, Vol. 11 No. 1, pp. 97-116. https://doi.org/10.1108/JIMA-02-2018-0036 
H. El-Gohary, (2015). Is it really Halal ?. Journal of Halal Tourism. Faculty of Business, Law, and Social Science, Birmingham University, United Kingdom Cairo University Business School, Cairo University, Egypt. $\underline{10.1016 / j . t m p .2015 .12 .013}$

Isa, S.M., Chin, P.N. and Mohammad, N.U. (2018). Muslim tourist perceived value: a study on Malaysia Halal tourism. Journal of Islamic Marketing, Vol. 9 No. 2, pp. 402-420. https://doi.org/10.1108/JIMA-11-2016-0083

Jafari, J., \& Noel S. (2014). Muslim World and Its Tourisms. Annuals of Tourism Research, 44, 1-19. https://doi.org/10.1016/j.annals.2013.08.011

Jajeli, R. (2013, July 11). Cheng Hoo Mosque, Masjid Unique Shaped Temple in Surabaya, (Online), retrieved from http://travel.detik.com/read/2013/07/11/164040/2299799/1383/masjidcheng-hoo- mosque-unique-shaped-temple-in-Surabaya , accessed 15 September 2016.

Jakarta.go.id (2017, January). Kota Tua Jakarta (Online), retrieved 19 September 2020 from https://jakarta.go.id/artikel/konten/2113/kota-tua-jakarta

Khan, F. and Callanan, M. (2017). The Halalification of tourism. Journal of Islamic Marketing, Vol. 8 No. 4, pp. 558-577. https://doi.org/10.1108/JIMA-01-2016-0001

Kovjanic, G. (2014). Islamic Tourism as a Factor of the Middle East Regional Development. TURIZAM, 18(1), 33-43. http://www.dgt.uns.ac.rs/turizam/arhiva/vol_1801_4.pdf

Liputan6 (2019, September). Trowulan, Educational and Entertaining Mojokerto Historical Site (Online), retrieved from https://surabaya.liputan6.com/read/4053045/trowulan-situs-sejarahmojokerto-yang-edukatif-dan-menghibur, accessed 19 September 2020

Mahmud, H. (2014). Promoting Islamic Tourism in Brunei: Towards Understanding Customers through the Shariah Compliant Hotel Concepts (Master's thesis). University of Nottingham, Nottingham NG7 2R, Britain. http://eprints.nottingham.ac.uk/27242/1/HajiMohamedHajiMahmud.pdf

Mastercard and CrescentRating (2018), "Global Muslim travel index 2018", available at: www.crescentrating.com/halal-muslim-travel-marketreports.html

Mohsin, A., Noriah R., \& Bader A. A. (2016). Halal Tourism: Emerging Opportunities. Tourism Management Perspectives, 19, 137-143. https://doi.org/10.1016/j.tmp.2015.12.010

Mohammed, A.r \& Mustafa I. (2016). Impact of Online WOM on Destination Trust and Intention to Travel: A Medical Tourism Perspective. Journal of Destination Marketing \& Management, 5, 192-201. https://doi.org/10.1016/j.jdmm.2015.12.005

Munirah, L., \& Ismail, H. N. (2012). Muslim Tourists' Typologi in Malaysia: Perspectives and Challenges. Proceedings of the Tourism and Hospitality International Conference. Malaysia: Department of Urban and Regional Planning, Faculty of Built Environment. https://www.researchgate.net/publication/303805265_Muslim_Tourists\%27 _Typology_in_Malaysia_Perspective_and_Challenges 
O'Cass, A., \& Phyra S. (2015). An Exploratory Study into Managing Value Creation in Tourism Service Firms: Understanding Value Creation Phases at The Intersection of The Tourism Service Firm and Their Customers. Tourism Management, 51, 186-200. https://doi.org/10.1016/j.tourman.2015.05.024

Othman, N., Rozian M. T., \& Shaya'a O. (2015). Maqasid Al Shariah in 2015. The Governance and Management Strategy of Islamic Tourism Businesses. Proceedings Paper of the International Conference on Maqasid Al Shariah in Public Policy and Governance, Malaysia: International Institute of Advanced Islamic Studies (IAIS). https://www.slideshare.net/OTTOMAN/maqasid-al-shariah-inmanagement-strategy-of-islamic-tourism-55409896

Pamukcu, H. and Sariisik, M. (2020). Suggestions for standardization of halal tourism in hospitality industry. Journal of Islamic Marketing, Vol. ahead-ofprint No. ahead-of-print. https://doi.org/10.1108/JIMA-04-2019-0078

Rahman, M., Moghavvemi, S., Thirumoorthi, T. and Rahman, M.K. (2020), "The impact of tourists' perceptions on halal tourism destination: a structural model analysis", Tourism Review, Vol. 75 No. 3, pp. 575594. https://doi.org/10.1108/TR-05-2019-0182

Ratnasari, Ririn, Tri, Gunawan, Sri, Septiarini, Dina, Fitrisia, Rusmita, Sylva, Alif, Kirana, Kusuma, Chandra. 2020. Customer Satisfaction between Perceptions of Environment Destination Brand and Behavioural Intention. International Journal of Innovation, Creativity and Change, Volume 10, Issue 12. https://www.ijicc.net/images/vol10iss12/101236_Ratnasari_2020_E_R.pdf

Ratnasari, R.T., Gunawan, S., Mawardi, I., Kirana, K.C. 2020. Emotional experience on behavioral intention for halal tourism. Journal of Islamic Marketing. https://doi.org/10.1108/JIMA-12-2019-0256

Republika. (2009, 19 February). Bali World's Best Destination Spa, (Online), retrieved from http://www.republika.co.id/berita/shortlink/32334, accessed 10 September 2019.

Ryan, C. (2016). Halal Tourism. Tourism Management Perspectives, 19, 121123. 10.1016/j.tmp.2015.12.014

Samori, Z., Nor Z. Md S., \& Mohammad K. M. (2016). Current Trends on Halal Tourism: Cases on Selected Asian Countries. Tourism Management Perspectives, 19, 131-

Shafaei, F., \& Badaruddin M. (2015). Malaysia's branding as a n Islamic Tourism Hub: a n Assessment . Malaysian Journal of Society and Space, 11(1), 97106.

https://www.researchgate.net/publication/282854273_Malaysia\%27s_brandi ng_as_an_Islamic_tourism_hub_An_assessment

Singh, S., Tapas R. D., \& Irina V. (2016). Tourism, Ecotourism and Sport Tourism: The Framework for Certification. Marketing Intelligence \& Planning, 34 (2), 236- 255. https://doi.org/10.1108/MIP-09-2014-0180

Siahaan, S. (2008). An Overview of Tourism Destination Marketing Perspective. Scientific Magazine Panorama Archipelago, Edition IV. 
Stephenson, M. L. (2014). Deciphering 'Islamic Hospitality': Developments, Challenges and Opportunities. Tourism Management, 40, 155-164. https://doi.org/10.1016/j.tourman.2013.05.002

Syazwan, Abu T. M. \& and Mohd Johan M. R. (2012). Issues in Halal Packaging: A Conceptual Paper. International Business and Management, 5(2). http://dx.doi.org/10.3968/j.ibm.1923842820120502.1080

Timothy, J. D. (2007). Tourism and Islam: Consideration of culture and duty. London and New York: Routledge Taylor \& Francis Group. https://doi.org/10.4324/9780203001073

UNWTO Tourism Highlights, (2010). https://www.eunwto.org/doi/book/10.18111/9789284413720

Vargas-Sánchez, A. and Moral-Moral, M. (2019), "Halal tourism: literature review and experts' view", Journal of Islamic Marketing, Vol. 11 No. 3, pp. 549-569. https://doi.org/10.1108/JIMA-04-2017-0039

Voskuil, R. P. (2007). Bandung, Citra sebuah kota. Departemen Planologi ITB bekerja sama dengan PT. Jagaddhita.

Ward, F. S. (2014). Performing Art as a Product of Cultural Tourism in Acehnese Cultural Context: Case Study of Saman Dance, Indonesia. Research Paper Department of Southeast Asian Studies Faculty of Arts and Social Sciences. University of Malaya for Partial Fulfillment of ATEA3321 (Cultural Tourism of South East Asian) .

Wijaya, S., Alison M., Thu-Huong N., \& Brian K. (2016). Exploration of Culinary Tourism in Indonesia: What Do the International Visitors Expect?. Asia Tourism Forum 2016 - The $12^{\text {th }}$ Biennial Conference of Hospitality and Tourism Industry in Asia (ATF-16) .

Wilson, J.A.J., Belk, R.W., Bamossy, G.J., Sandikci, O., Kartajaya, H., Sobh, R., Liu, J. and Scott, L. (2013). Crescent marketing, Muslim geographies and Brand Islam reflections from the JIMA senior advisory board. Journal of Islamic Marketing, $\quad$ Vol. 4 No. 1, pp. 22-50. https://doi.org/10.1108/17590831311306336

Yagmur, Y., Ehtiyar, R. and Aksu, A. (2019). Evaluation of halal tourism in terms of bibliometric characteristics. Journal of Islamic Marketing, Vol. ahead-ofprint No. ahead-of-print. https://doi.org/

Yaman, R., Alias, Z., \& Ishak, N. M. (2012). Beauty treatment and spa design from Islamic perspective. Procedia-Social and Behavioral Sciences, 50, 492-501.https://doi.org/10.1016/j.sbspro.2012.08.053 